\title{
Effect of cuprous cyanide, dry and wet milling on the selective flotation of galena and sphalerite
}

\author{
M.D. Seke and P.C. Pistorius
}

\begin{abstract}
Batch flotation tests of a lead-zinc sulphide composite ore from the Rosh Pinah Mine have been carried out at $\mathrm{pH} 8.5$ in the presence of copper cyanide complexes. These copper cyanide complexes are often found in the recycled water that is used in the milling and the lead flotation circuits. Flotation results have shown that cuprous cyanide complexes can activate sphalerite. In addition, the activation and subsequent flotation of sphalerite was greater when the composite was dry milled as compared to wet milling. Surface analysis of copper(I)-activated sphalerite samples was studied by X-ray photoelectron spectroscopy (XPS). XPS results showed the presence of copper species on the surface of sphalerite after activation with cuprous cyanide complexes. The copper species could be removed from the surface of sphalerite after treatment with sodium cyanide. This explains, amongst others reasons, the high cyanide requirement at Rosh Pinah Mine for the efficient depression of sphalerite in the lead flotation circuit.
\end{abstract}

\section{Article Outline}

1. Introduction

2. The electrochemical oxidation of copper cyanide complexes

3. Experimental

3.1. Materials, reagents and solutions

3.2. Flotation

3.3. X-ray photoelectron spectroscopy

3.3.1. Activation of sphalerite with $\mathrm{Cu}(\mathrm{II})$ and $\mathrm{Cu}(\mathrm{I})$ ions

3.4. Fourier transform infrared spectroscopy

4. Results and discussions

4.1. Effect of grinding environment on the pulp chemistry and flotation

4.2. Influence of cuprous cyanide on the flotation recoveries

4.3. X-ray photoelectron spectroscopy on the activation of sphalerite

5. Conclusion

Acknowledgements

References 


\section{Introduction}

The flotation results of various studies have shown that the quality of the process water in general, and recirculating water in particular, can have an adverse effect on the flotation selectivity of complex sulphide minerals (Malysiak et al., 2003, Ng'andu, 2001, Levay et al., 2001, Rao and Finch, 1989 and Broman, 1980). This is mainly due to one or more of the following factors:

- residual xanthates and their oxidation products which adsorb unselectively on most sulphides;

- metallic ions such as $\mathrm{Cu}^{2+}, \mathrm{Pb}^{2+}, \mathrm{Fe}^{2+}$ which cause inadvertent activation;

- alkaline earth metal ions which may activate the non-sulphide gangue; and

- variation in the slurry $\mathrm{pH}$ and pulp potential in the milling and/or the flotation circuit.

Williams and Phelan (1985) showed that the presence of zinc ions (in the region of $200 \mathrm{ppm}$ ) in the recirculating water ( $\mathrm{pH} \mathrm{3),} \mathrm{which} \mathrm{was} \mathrm{used} \mathrm{in} \mathrm{the} \mathrm{mill,} \mathrm{affected} \mathrm{the}$ recovery of sphalerite in the subsequent zinc circuit $(\mathrm{pH} 9.5)$ at the Woodlawn Mines (Australia) due to the presence of colloidal hydroxide on the surface of the mineral. The adverse effect of zinc ions on the flotation recovery of sphalerite was eliminated by treating the process water to remove zinc ions before the water entered the mill.

Broman (1980) used water from a tailing pond to study the effect of process water on the flotation selectivity of a $\mathrm{Cu}-\mathrm{Zn}$ ore (chalcopyrite and sphalerite). He showed that the grade of zinc in the copper concentrate increased with the use of the recycle water, while the grade of copper decreased. Moreover, the grade of copper increased in the copper tailings, showing poorer flotation selectivity between copper and zinc in the copper concentrate. The presence of zinc in the copper concentrate was partly due to the inadvertent activation of sphalerite by the dissolved copper ions from the recycle water.

Levay et al. (2001) and Williams and Phelan (1985) showed that variation in $\mathrm{pH}$, Eh, and dissolved oxygen will usually affect the chemistry of the species present in the water stream. Thus, the chemical composition of recycle water will depend upon the minerals being processed, the reagent suite and the electrochemical environment of the milling and flotation circuit.

The present study focused on a more integrated and practical approach to the inadvertent activation of sphalerite in the lead flotation circuit by taking into account the concentration of the dissolved ions in the recirculating water. An understanding of this kind of activation is important for optimizing the reagent suite and improving the flotation selectivity between galena and sphalerite in the lead flotation circuit at Rosh Pinah Mine. 
At Rosh Pinah Mine, water from the lead rougher tailings thickener (P22) and lead concentrate thickener are the main source of process water used in the milling and lead flotation circuit. The overflow of the thickener (P22), in which the galena rougher tailings are dewatered, is used to dilute the product from the primary ball mill and from the primary cyclone. Coetzer et al. (2003) conducted a survey on the composition of the water from different streams at the Rosh Pinah Mine and the results are summarised in Table 1.

-Table 1 .

Detailed analyses of water resources of Rosh Pinah Mine (Coetzer et al., 2003)

\begin{tabular}{|l|l|l|}
\hline & Lead tailings thickener (P22) & Lead concentrate thickener \\
\hline Quantity $\left(\mathrm{m}^{3} / \mathrm{h}\right)$ & 4 & 120 \\
\hline $\mathrm{pH}$ & 8.5 & 8.9 \\
\hline Total alkalinity & 219 & 197 \\
\hline $\mathrm{Cu}$ & 17.2 & 30 \\
\hline $\mathrm{Zn}$ & 0.34 & 10 \\
\hline $\mathrm{Pb}$ & 0.33 & 0.5 \\
\hline $\mathrm{Fe}$ & 0.09 & 0.12 \\
\hline $\mathrm{Ba}$ & 0.22 & 0.12 \\
\hline Ag & 0.03 & 2.75 \\
\hline Free cyanide & 53 & 60 \\
\hline TDS & 949 & 825 \\
\hline
\end{tabular}

Assays in mg/l.

TDS $=$ total dissolved solids

Since sodium cyanide is added in the mill, it is likely that most of the copper in the mill discharge slurry will be present as cupro-cyano complexes. However, due to the high dosage of free cyanide added in the mill, it is possible to still find residual amount of free cyanide in the water stream from the thickener P22. 
Based on the mechanism of activation of sphalerite by $\mathrm{Cu}(\mathrm{II})$ ions, the activation by copper cyanide complexes can only occur if the copper cyanide complexes undergo some decomposition/oxidation to make the copper available. It is believed that the electrochemical conditions in the thickener might promote the degradation of copper cyanide complexes. Although there is not a clear mechanism by which copper cyanide complexes themselves activate sphalerite, the electrochemical oxidation of copper cyanide can be used to formulate such a mechanism, as discussed in Section 2.

\section{The electrochemical oxidation of copper cyanide complexes}

The need for treating large quantities of metal cyanide wastewater in the mining industry has resulted in the study of the electrochemical oxidation of alkaline copper cyanide solutions (Djokić, 2002, Cheng et al., 2002, Casella and Gatta, 2000 and Dudek and Fedkiw, 1999). These authors have observed that copper from cyanide complexes such as $\mathrm{Cu}(\mathrm{CN})_{2}^{-}$and $\mathrm{Cu}(\mathrm{CN})_{3}^{2-}$ can be deposited as $\mathrm{Cu}(\mathrm{OH})_{2}, \mathrm{CuO}$ and $\mathrm{Cu}_{2} \mathrm{O}$ on the surface of glassy carbon, gold and platinum electrodes following the oxidation of cyanide at high potential (500 mV SCE). Fig. 1 shows that the oxidation of copper(I) from copper cyanide complexes can occur at higher potential.

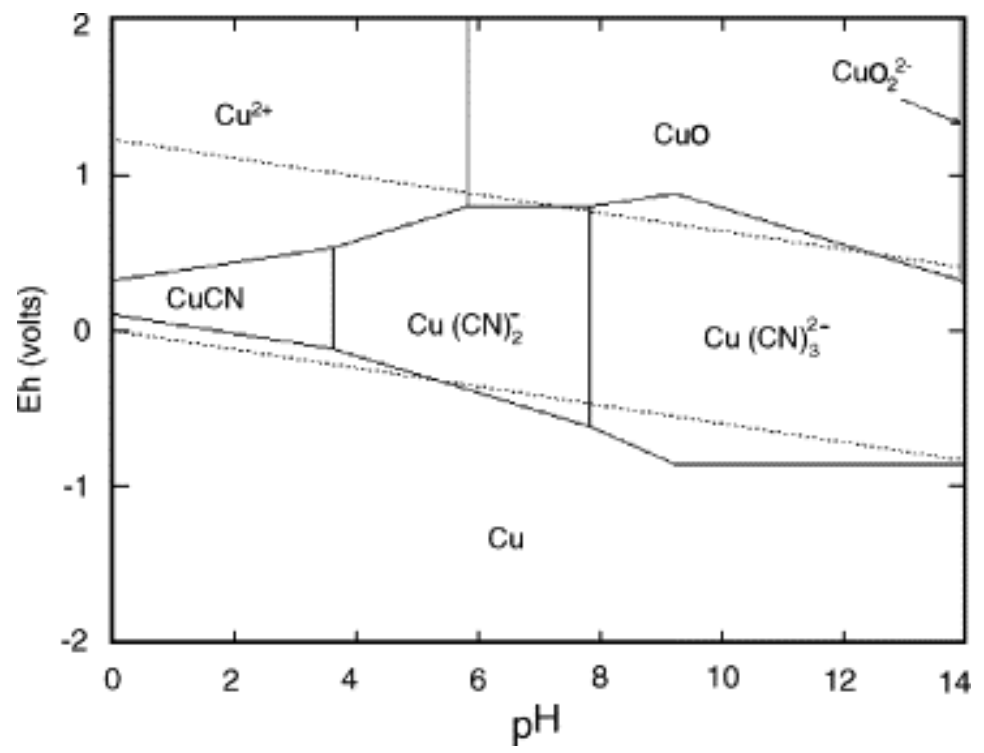

Fig. 1. Pourbaix diagram of the $\mathrm{Cu}-\mathrm{CN}-\mathrm{H}_{2} \mathrm{O}$ system at $25^{\circ} \mathrm{C} .[\mathrm{Cu}]=5 \times 10^{-5} \mathrm{M}$, $\left[\mathrm{CN}^{-}\right]=6 \times 10^{-4} \mathrm{M}$. Stabcal software, NBS database (Huang, 2003).

Casella and Gatta (2000) observed that the concentration of copper on both the glassy carbon and the platinum electrodes increased with increasing applied potential. They showed that the loading of copper on both electrodes started at potentials where copper cyanide species are still thermodynamically stable. 
A mechanism which support the simultaneous oxidation/dissociation of $\mathrm{Cu}\left(\mathrm{CN}_{\mathrm{d}^{1-x}}^{-\pi}\right.$ complex species followed by the deposition of copper oxide/hydroxide was proposed by Casella and Gatta (2000):

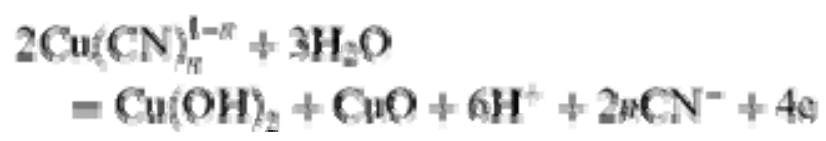

After an initial incipient copper deposition, further deposition was obtained by simple immersion of the electrode in a cyanocuprate solution. Thus, the first monolayer of copper acted as a catalyst for further chemisorption of copper oxide/hydroxide (Casella and Gatta, 2000). Although potential of $500 \mathrm{mV} \mathrm{SCE}$ is not likely to be achieved in flotation pulp, the possibilities of sphalerite activation by copper cyanide species alone cannot be ignored.

To date, most of the work conducted on the inadvertent activation of sphalerite has focused mainly on the effect of $\mathrm{Cu}$ (II) ions (Chen and Yoon, 2000, Pattrick et al., 1999, Laskowski et al., 1997, Prestidge et al., 1997 and Finkelstein, 1997). The copper concentration used in most previous studies was higher than that found in the recirculating water. Since the identity of copper species in the recirculating water at the Rosh Pinah Mine is not known, it is possible that the copper cyanide species could themselves affect the flotation selectivity between sphalerite and galena. Interactions between copper cyanide species and sphalerite have not been studied extensively, and are of fundamental importance in selective flotation, especially when water from the lead rougher tailings is recycled to the milling and flotation circuit.

\section{Experimental}

\subsection{Materials, reagents and solutions}

The lead-zinc composite ore $(-9 \mathrm{~mm})$ used in this study was obtained from the crushing plant at the Rosh Pinah Mine in Namibia. The sample was screened at $1.7 \mathrm{~mm}$ and the oversize fraction crushed to $-1.7 \mathrm{~mm}$. A sub-sample was removed for head assays. The chemical composition of the composite used in this study was determined using a sequential XRF spectrometer ARL 9400-241XP+ of which the results are shown in Table 2. The remainder of the sample was used for the flotation testwork. In each case, a $1 \mathrm{~kg}$ batch sample was milled, either dry or at $67 \%$ solids (w/w), in an unlined laboratory mild steel mill $(\varnothing 200 \times 250 \mathrm{~mm})$ with mild steel rods $(11 \mathrm{~kg})$ for 8 min to achieve the target grind of $80 \%$ passing $100 \mu \mathrm{m}$. The particle size distributions of the ground products were determined using a Malvern Mastersizer 2000 instrument. 
Table 2.

The average chemical analysis of the lead-zinc composite sample used in this study (wt.\%)

\begin{tabular}{|l|l|l|l|l|l|l|l|l|}
\hline $\mathbf{P b}$ & $\mathrm{Zn}$ & $\mathrm{Cu}$ & $\mathrm{Fe}$ & $\mathrm{S}$ & $\mathbf{C a O}$ & $\mathbf{M g O}$ & $\mathbf{A l}_{2} \mathbf{O}_{3}$ & $\mathbf{S i O}_{2}$ \\
\hline 1.9 & 7.0 & 0.12 & 3.7 & 3.9 & 18.7 & 8.2 & 4.1 & 49.2 \\
\hline
\end{tabular}

Natural sphalerite minerals from Elmwood Mine, Carthage (Tennessee, USA), were obtained from Ward's Natural Science and cut into a $10 \times 10 \mathrm{~mm}$ sample. These samples were used to study the activation of sphalerite by cuprous cyanide and copper sulphate.

Sodium propyl xanthate (SNPX) and potassium butylxanthate (PNBX) from Senmin (South Africa) were used as collectors. Senfroth 9325 (Polypropylene glycol) from Senmin (South Africa) was used as frother. The xanthate was purified by dissolution in acetone and reprecipitation with petroleum ether as proposed by Rao (1971). Xanthate solutions were prepared daily. Analytical grade copper nitrate $\left(\mathrm{Cu}\left(\mathrm{NO}_{3}\right)_{2}\right)$ from Bio-Zone Chemicals (South Africa) was used for the activation of sphalerite by $\mathrm{Cu}$ (II) ions. Analytical grade copper cyanide $(\mathrm{CuCN})$ and sodium cyanide $(\mathrm{NaCN})$ from Saarchem (South Africa) were used for the preparation of solution containing copper cyanide complexes. Copper cyanide stock solutions $\left(10^{-4}\right.$ and $\left.10^{-3} \mathrm{M} \mathrm{Cu}(\mathrm{I})\right)$ were prepared by addition of $\mathrm{CuCN}$ powder to a sodium cyanide solution at a $\mathrm{CN}^{-} / \mathrm{Cu}$ molar ratio of $3: 1$ and at $\mathrm{pH}$ of 10.5 , which was maintained by additions of sodium hydroxide solutions.

\subsection{Flotation}

A Denver D12 flotation machine, a $3 \mathrm{dm}^{3}$ flotation cell and laboratory tap water were used for the batch flotation tests. All flotation experiments were carried out at about 33\% (w/w) solid. The impeller speed was set at $1250 \mathrm{rpm}$ and the air flow rate was $6 \mathrm{dm}^{3} \mathrm{~min}^{-1}$. Although no attempt was made to control the pulp potential and dissolved oxygen, they were monitored throughout the experiments. The pulp potential was measured using a platinum electrode and a $\mathrm{Ag} / \mathrm{AgCl}$ reference electrode. However, measured potential values are reported relative to the standard hydrogen electrode. The platinum electrode $(0.5 \mathrm{~mm}$ Pt wire) was calibrated with a ferrous-ferric solution as described by Light (1972). The platinum electrode was cleaned with nitric acid and distilled water after every experiment to remove any coating on its surface. A Keithley Electrometer (model 614) was used for the potential measurements.

Flotation tests were carried out at the natural $\mathrm{pH}(8.5 \pm 0.2)$ of the pulp and room temperature $\left(22 \pm 2{ }^{\circ} \mathrm{C}\right)$, which were measured with an Orion $\mathrm{pH}$ meter model 420 . The dissolved oxygen in the flotation cell was monitored with the WTW OX191 oxymeter. After transferring the ore into the flotation cell, the desired amount of $\mathrm{Cu}(\mathrm{I})$ was added as copper cyanide complexes, and then the pulp was conditioned for $10 \mathrm{~min}$. The xanthate 
(50 g SNPX per ton of dry ore) was then added and the pulp was conditioned for 3 min after which the frother ( $60 \mathrm{~g} / \mathrm{t}$ Senfroth 9325$)$ was added and conditioned for a further $1 \mathrm{~min}$. After starting the air flow, the froth was removed by hand scraping every $15 \mathrm{~s}$. Incremental rougher concentrates were collected after 1, 2, 4 and $10 \mathrm{~min}$, unless stated otherwise. The volume of the pulp in the flotation cell was kept constant by additions of tap water using a pulp level control device. Following the flotation tests, the concentrates and tailings were dried and analysed using XRF. Cumulative recoveries were calculated from the masses and chemical analyses of the concentrates and the tailings.

\subsection{X-ray photoelectron spectroscopy}

\subsubsection{Activation of sphalerite with $\mathrm{Cu}(\mathrm{II})$ and $\mathrm{Cu}(\mathrm{I})$ ions}

For surface analysis of sphalerite reference sample, the sample was wet ground using 600 grit silicon carbide paper, washed thoroughly with distilled water, and then introduced into the spectrometer. Other sphalerite samples were conditioned in $200 \mathrm{~cm}^{3}$ solutions (air-saturated) of copper cyanide complexes or copper nitrate $\left(10^{-2}\right.$ and $\left.10^{-3} \mathrm{M}\right)$ for $30 \mathrm{~min}$ at $\mathrm{pH}$ 10.5. After conditioning, the sphalerite sample was washed with water and dried before being introduced into the XPS for analysis. After XPS analysis, the sample was treated with $200 \mathrm{~cm}^{3}$ of sodium cyanide solution $\left(10^{-2} \mathrm{M}\right)$, washed with distilled water, dried and then reintroduced in the instrument and analysed again.

XPS spectra were obtained using a Perkin Elmer PHI Model 5400 spectrometer equipped with a $\mathrm{Mg} / \mathrm{Al}$ dual anode source. An achromatic $\mathrm{MgK}_{\alpha} \mathrm{X}$-ray $(1253.6 \mathrm{eV})$ source was operated at $300 \mathrm{~W}, 15 \mathrm{kV}$, and $20 \mathrm{~mA}$. The vacuum pressure in the analyser chamber was at least $10^{-9}$ Torr during analysis. The instrument was calibrated against the $\mathrm{C} 1 \mathrm{~s}$ peak at $284.6 \mathrm{eV}$. Spectra were obtained at a take off angle of $45^{\circ}$ to the sphalerite surface with a pass energy of $17.9 \mathrm{eV}$. Data analysis was performed using PHI XPS software (version 2.0). Elemental atomic concentrations were calculated from the XPS peak areas and the respective sensitivity factor. Spectra presented in this study were corrected for background charging. Charge corrections were made using $\mathrm{C} 1 \mathrm{~s}$ peak at $284.6 \mathrm{eV}$.

\subsection{Fourier transform infrared spectroscopy}

FT-IR spectra of copper cyanide solutions were obtained using a Perkin Elmer GX spectrum 2000 Fourier Transform Infrared Spectrometer with a ZnSe horizontal ATR accessory. Fifteen scans were recorded over the frequency range of $4000-400 \mathrm{~cm}^{-1}$ and Fourier transformed to give a resolution of $8 \mathrm{~cm}^{-1}$. The software Spectrum version 2 for Windows (Perkin Elmer) was used for the acquisition and processing of data.

\section{Results and discussions}

\subsection{Effect of grinding environment on the pulp chemistry and flotation}

The effects of dry and wet milling of the sample on the pulp potential and dissolved oxygen are shown in Fig. 2 and Fig. 3. The low dissolved oxygen and pulp potential 
measured after wet milling indicated the presence of oxygen consumers such as metallic iron and labile sulphides in the wet milled pulp. In addition, the dissolved oxygen was unchanged during the conditioning stage of the wet milled pulp. The dissolved oxygen and pulp potential were higher after dry milling of the composite. Although the pulp potential dropped slightly before the addition of the collector for the composite sample which had been ground in a dry environment (Fig. 2), the pulp potential of the dry milled pulp was still more positive than that of the wet milled pulp at the time of xanthate addition. However, when the cuprous cyanide species was added in the flotation cell the dissolved oxygen and pulp potential for the dry milled composite (Fig. 3) decreased substantially. This indicated that some oxidation/reduction reactions were occurring at different stages of the flotation test.
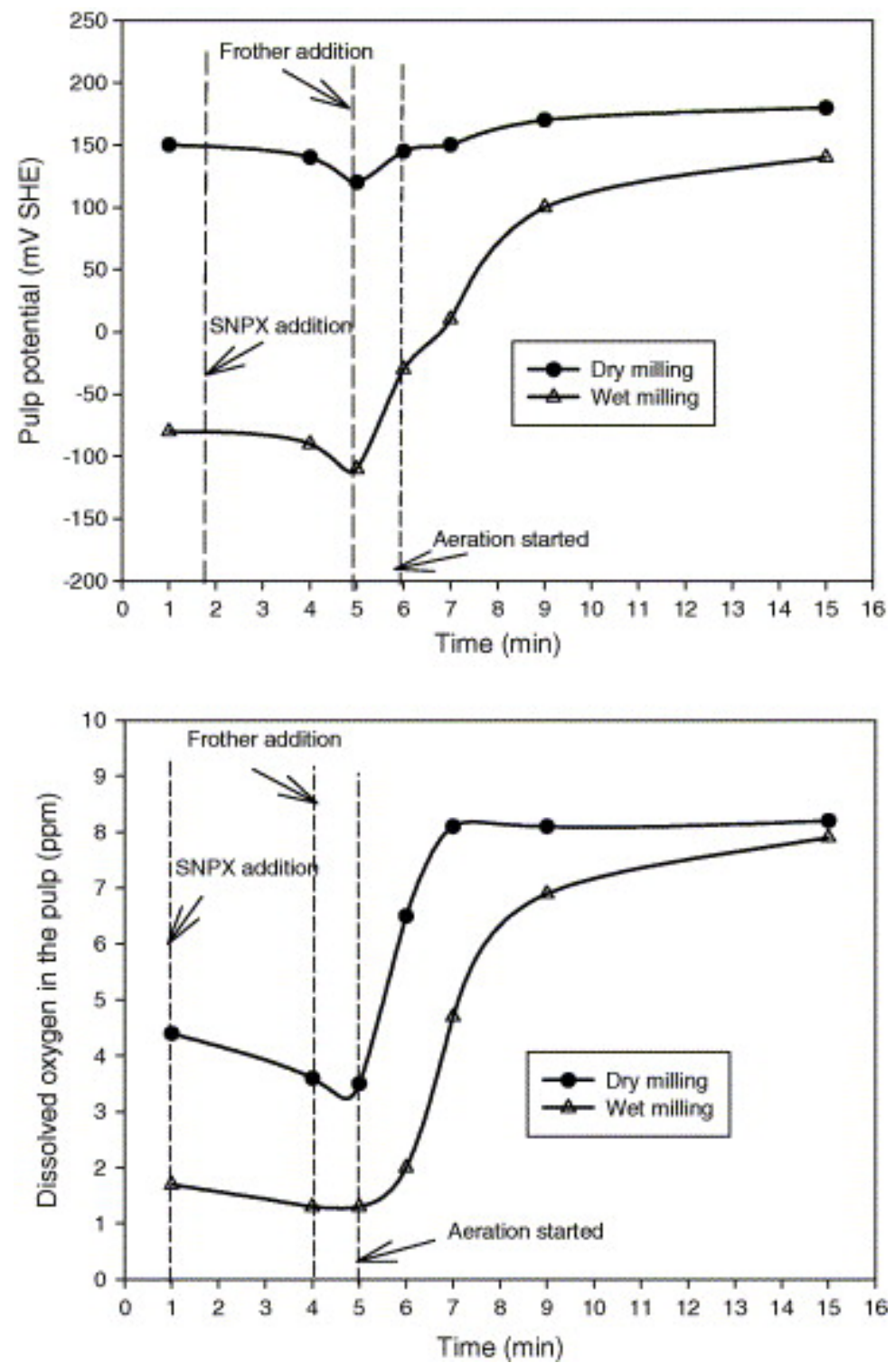

Fig. 2. Evolution of the pulp potential and the dissolved oxygen concentration in the flotation cell during the flotation of a Rosh Pinah composite ground in either a dry or wet 
environment in a steel mill. Tests were carried out before the activation with cuprous cyanide species.
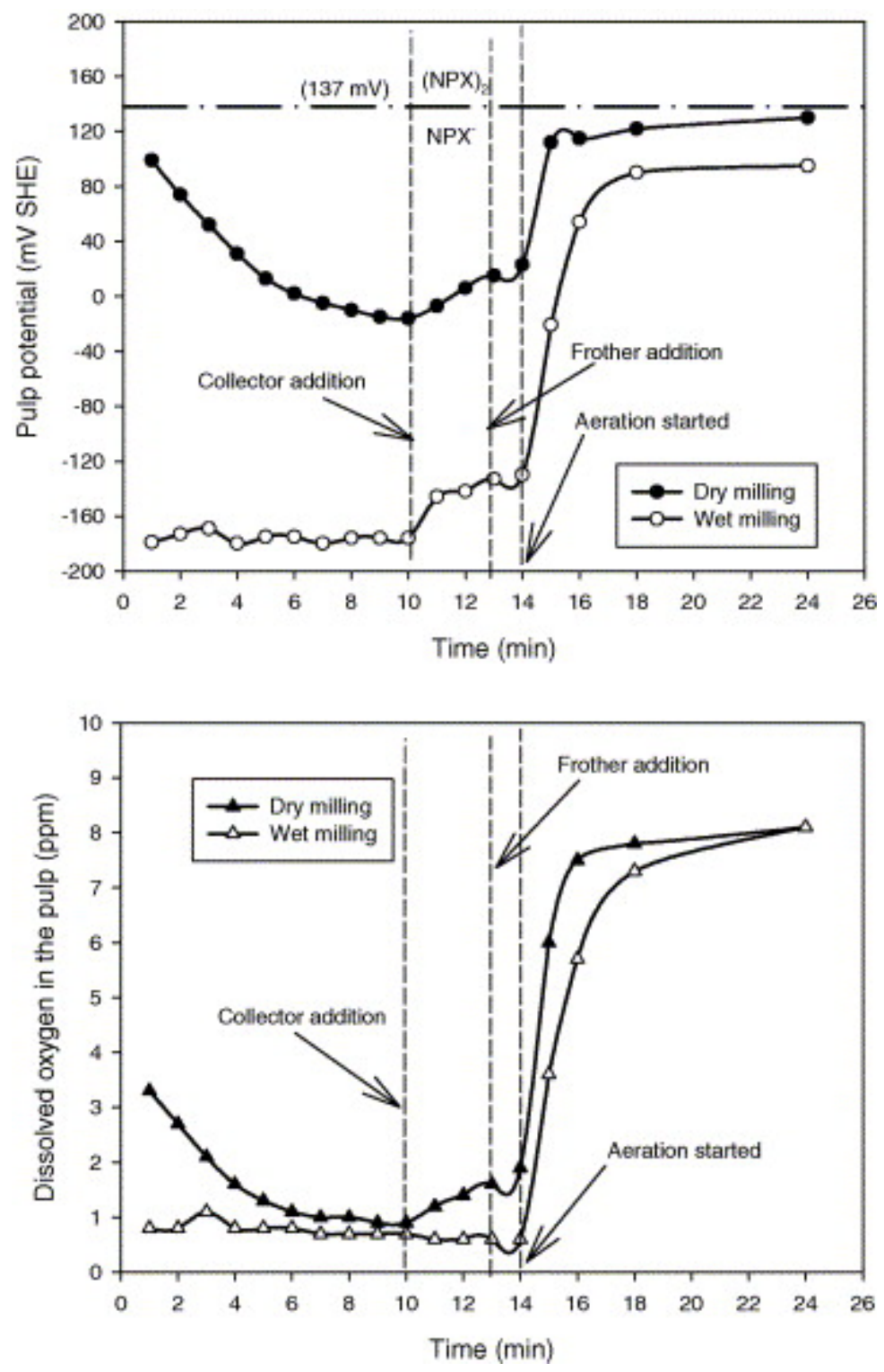

Fig. 3. Evolution of the pulp potential and the dissolved oxygen concentration in the flotation cell during the flotation of a Rosh Pinah composite ground in either a dry or wet environment in a steel mill. Flotation tests were carried out in the presence of $10^{-4} \mathrm{M}$ cuprous cyanide complexes. The activator was added at the beginning of the process $(t=0 \mathrm{~min})$. The reversible half-cell potential for the $\mathrm{NPX}^{-} /(\mathrm{NPX})_{2}$ reaction is also shown for a SNPX concentration of $1.4 \times 10^{-4} \mathrm{M}$ (horizontal dash-dot line in the upper graph). 
The sharp rise in the pulp potential with the starting of aeration was clearly due to the addition of oxygen to the pulp. The differences in the pulp potentials between the dry and wet milled sample diminished by the end of the flotation stage. Thus, it was clear that the milling environment contributed to the variation in the pulp potential prior to the activation and conditioning stages of the composite. However, the dissolved oxygen and pulp potential observed during the collection of the rougher concentrate were mainly controlled by the aeration.

The reversible potential for the dithiolate-thiolate reaction was calculated from the standard half-cell potential and the concentration of the species using the Nernst equation (Eq. (2)).

$$
E=E^{0}-(0.059 / 2) \log \left(\left[\mathrm{X}^{-}\right]^{2} /\left[\mathrm{X}_{2}\right]\right)
$$

where $\left[\mathrm{X}^{-}\right]$and $\left[\mathrm{X}_{2}\right]$ are the xanthate and dixanthogen concentration, respectively. For the concentration of SNPX $\left(1.4 \times 10^{-4} \mathrm{M}\right)$ used in this study, the oxidation of SNPX to its dithiolate species can occur at potentials above $137 \mathrm{mV}$, assuming $\left[\mathrm{X}_{2}\right]=1$. The standard redox potential for SNPX is $E^{0}=-0.091 \mathrm{~V}$ SHE (Crozier, 1991). As seen in Fig. 3, the formation of dixanthogen in the flotation pulp was not thermodynamically favourable when the collector was added in the slurry. This is in line with the proposal by Buckley and Woods (1997) that chemisorption of xanthate was the thermodynamically favourable process.

The measurements of the pulp chemistry have shown that higher dissolved oxygen and more positive pulp potential were observed when the composite had been ground in a dry environment. Thus, it is possible that further oxidation of minerals could occur in the flotation cell due to the presence of dissolved oxygen prior to aeration of the pulp. In contrast, more negative pulp potentials and low dissolved oxygen were observed after wet milling of the ore; these would tend to diminish oxidation of minerals during the conditioning stage.

Since it is known that the flotation of sphalerite from the complex lead-zinc sulphide minerals is enhanced under more oxidizing conditions, the flotation recovery of sphalerite from the Rosh Pinah composite was expected to be higher after dry milling, with resulting poorer flotation selectivity between galena and sphalerite. This effect is visible in the results of flotation tests on the Rosh Pinah composite in the presence of $50 \mathrm{~g} / \mathrm{t}$ SNPX (Fig. 4). The metallurgical data of the lead concentrate are summarised in Table 3 (cuprous cyanide was not added for these flotation tests). These results were confirmed under various flotation conditions (e.g. higher xanthate dosage, flotation tests in duplicate) and results are reported elsewhere (Seke, 2005). 


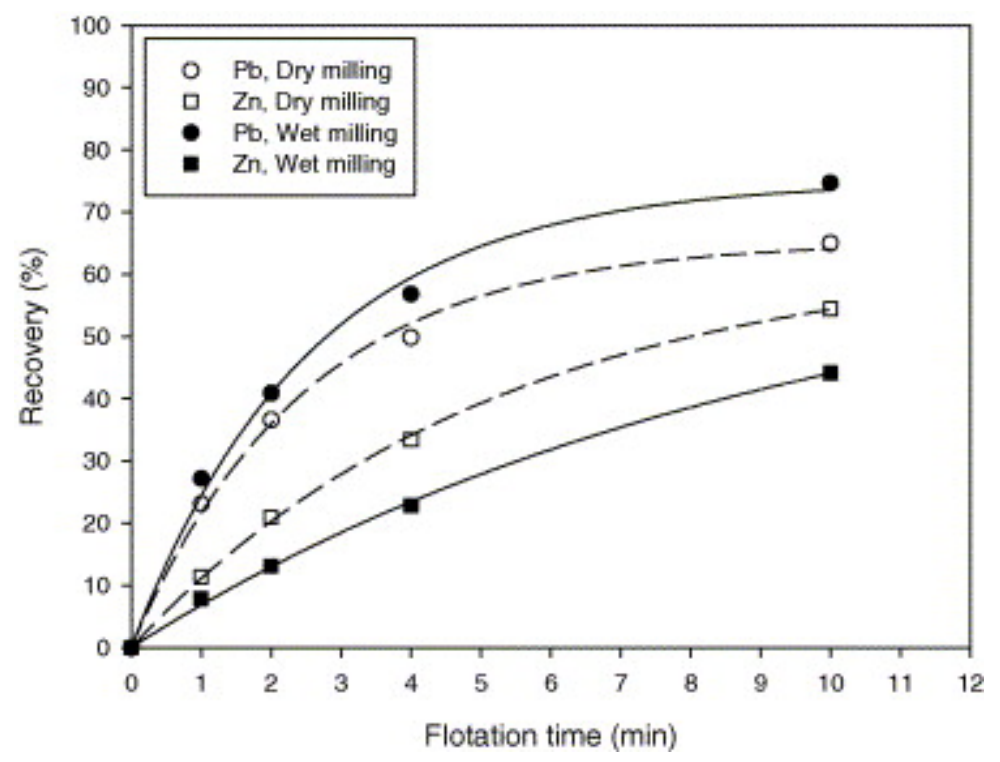

Fig. 4. Flotation recovery of galena and sphalerite from a Rosh Pinah composite with $50 \mathrm{~g} / \mathrm{t}$ SNPX at $\mathrm{pH} 8.5$ under various grinding conditions. Solid lines (after wet milling, $67 \%$ solids), dashed line (after dry milling).

Table 3.

Metallurgical results of the lead rougher concentrate after wet and dry milling of the Rosh Pinah composite

\begin{tabular}{|l|l|l|l|l|l|l|}
\hline Milling type & $\mathbf{E h}^{\text {a }}(\mathbf{m V}$ SHE) & Mass pull (\%) & \multicolumn{3}{|c|}{ Recovery (\%) } & \multicolumn{3}{|c|}{ Grade (\%) } \\
\hline & & & Pb & $\mathbf{Z n}$ & Pb & $\mathbf{Z n}$ \\
\hline Wet & $-80 /+140$ & 17.5 & 74.1 & 44.2 & 8.5 & 19.3 \\
\hline Dry & $+150 /+180$ & 16.5 & 65.0 & 54.7 & 8.8 & 27.5 \\
\hline
\end{tabular}

${ }^{a}$ Eh measured after 1 min of conditioning time and at the end of flotation.

The results presented in Table 3 shows that the flotation selectivity between galena and sphalerite was adversely affected by dry milling. The flotation recoveries of sphalerite were approximately $44 \%$ and 55\% when the composite was ground in a wet and dry environment, respectively. In addition, the grade of zinc in the lead concentrate was higher $(27 \%)$ after dry milling as compared to $19 \%$ when the composite was wet milled. It was observed that the concentrate mass pull was almost independent of the milling environment. 
The effect of cuprous cyanide species on the flotation response of the Rosh Pinah composite sample is presented in the following section.

\subsection{Influence of cuprous cyanide on the flotation recoveries}

After the milling stage, the pulp was transferred into the flotation cell and diluted to $33 \%$ solids prior to flotation. The required amount of cuprous cyanide solution was added to activate sphalerite and the pulp was conditioned for $10 \mathrm{~min}$ before the addition of xanthate. The cuprous cyanide solution was prepared and analysed using FTIR spectrometer as described in Section 3. Fig. 5 shows that a peak assigned to $\mathrm{Cu}\left(\mathrm{CN}_{3}^{2-}\right.$ was observed at the wave number of $2093 \mathrm{~cm}^{-1}$ (Lukey et al., 1999). A ferrocyanide solution was also analysed for comparison purposes only. A peak assigned to the ferrocyanide species was observed at a wave number of $2037 \mathrm{~cm}^{-1}$. The spectrum of copper cyanide confirms that $\mathrm{Cu}(\mathrm{CN})_{3}^{2-}$ species were in solution when the activation of sphalerite by $\mathrm{Cu}(\mathrm{I})$ was studied.

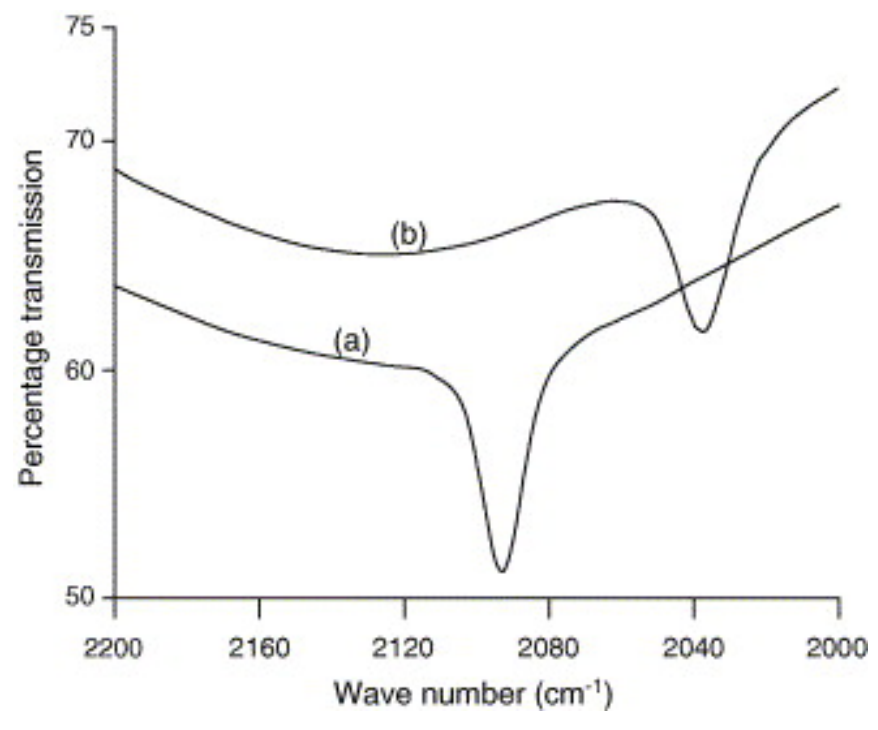

Fig. 5. FTIR spectra of aqueous cuprous cyanide and ferrocyanide species at $\mathrm{pH}$ 10.5: (a) $[\mathrm{Cu}(\mathrm{I})]=10^{-3} \mathrm{M}$ and $\mathrm{CN} / \mathrm{Cu}$ molar ratio of 3 and (b) $10^{-2} \mathrm{M}$ ferrocyanide.

The effect of cuprous cyanide and type of milling on the recovery of sphalerite in the lead concentrate is shown in Fig. 6 and Fig. 7. The metallurgical results of the lead rougher concentrate are summarised in Table 4. 

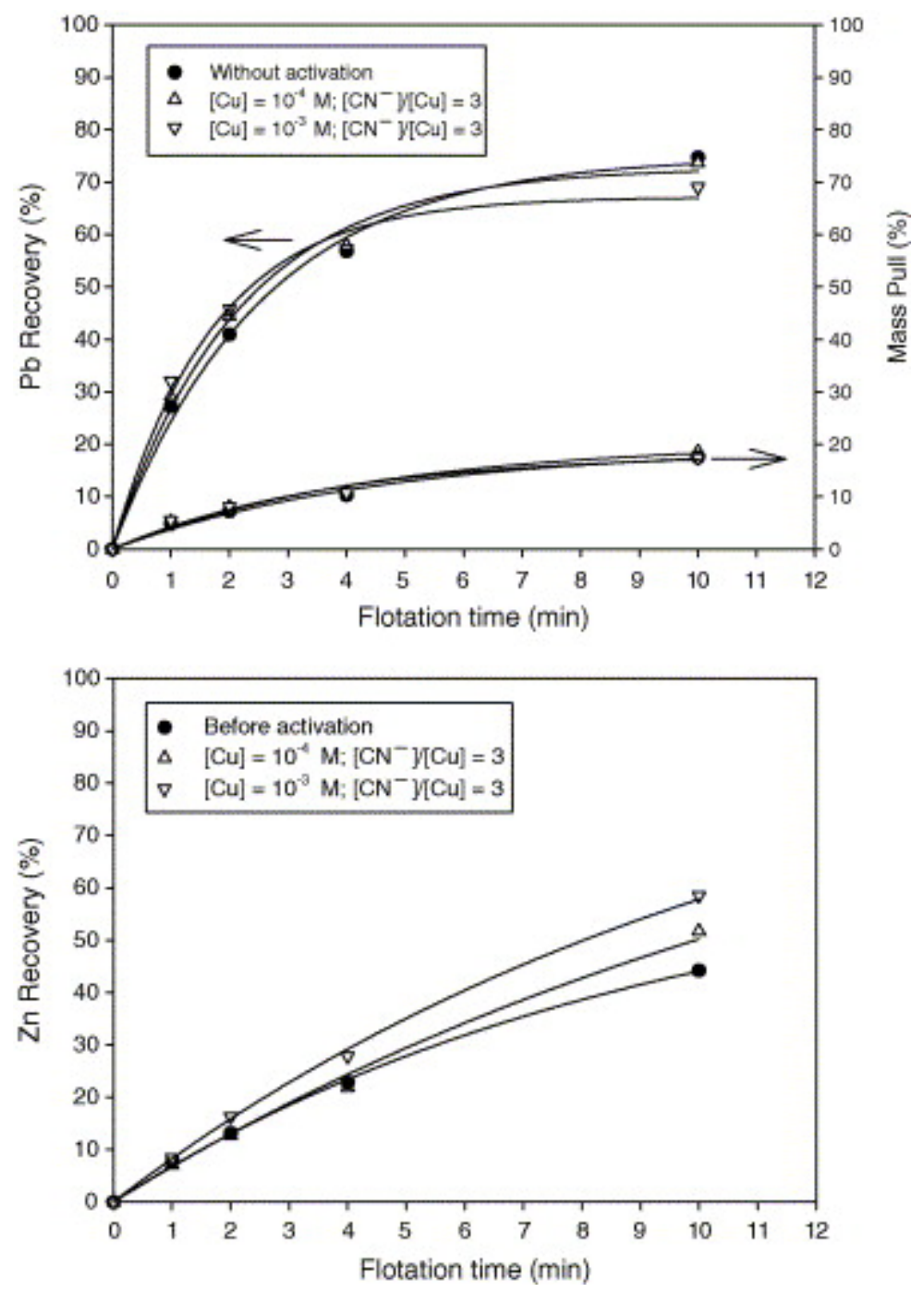

Fig. 6. Effect of copper cyanide dosages on the concentrate mass pull and flotation recoveries of galena and sphalerite after wet milling of a Rosh Pinah composite sample. Solid lines represent fitted curves. Flotation conditions: $50 \mathrm{~g} / \mathrm{t} \mathrm{SNPX}$ and $\mathrm{pH}$ 8.5. 

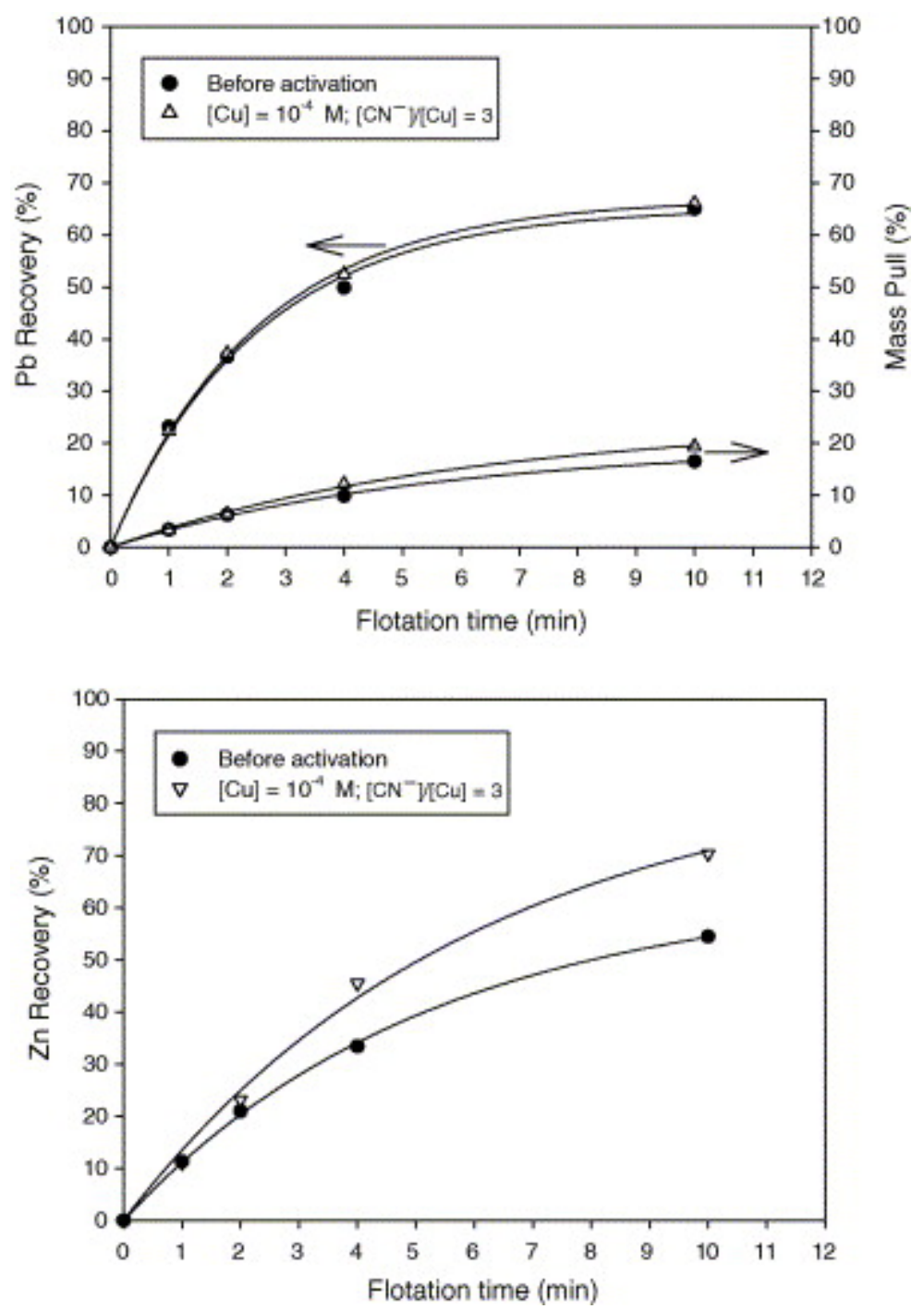

Fig. 7. Effect of copper cyanide dosages on the concentrate mass pull and flotation recoveries of galena and sphalerite after dry milling of a Rosh Pinah composite sample. Solid lines represent fitted curves. Flotation conditions: $50 \mathrm{~g} / \mathrm{t} \mathrm{SNPX}$ and $\mathrm{pH}$ 8.5. 
Table 4.

Flotation results of the Rosh Pinah composite at $50 \mathrm{~g} / \mathrm{t}$ SNPX and various dosages of cuprous cyanide after wet and dry milling

\begin{tabular}{|c|c|c|c|c|c|c|c|}
\hline \multirow[t]{2}{*}{$\begin{array}{l}\text { Milling } \\
\text { type }\end{array}$} & \multirow[t]{2}{*}{$\begin{array}{l}\mathrm{Cu}(\mathrm{I}) \text { concentration } \\
\left(\left[\mathrm{CN}^{-}\right] /[\mathrm{Cu}]=3\right)\end{array}$} & \multirow[t]{2}{*}{$\begin{array}{l}\mathrm{Eh}^{\mathrm{a}}(\mathbf{m V} \\
\mathrm{SHE})\end{array}$} & \multirow[t]{2}{*}{$\begin{array}{l}\text { Mass } \\
\text { pull }(\%)\end{array}$} & \multicolumn{2}{|c|}{$\begin{array}{l}\text { Recovery } \\
(\%)\end{array}$} & \multicolumn{2}{|c|}{$\begin{array}{l}\text { Grade } \\
(\%)\end{array}$} \\
\hline & & & & $\mathbf{P b}$ & $\mathbf{Z n}$ & $\mathbf{P b}$ & $\mathbf{Z n}$ \\
\hline \multirow[t]{3}{*}{ Wet } & 0 & $-80 /+140$ & 17.5 & 74.1 & 44.2 & 8.5 & 19.3 \\
\hline & $10^{-4} \mathrm{M}$ & $-179 /+95$ & 18.6 & 73.7 & 51.8 & 8.4 & 23.1 \\
\hline & $10^{-3} \mathrm{M}$ & $-180 /+90$ & 17.5 & 69.1 & 58.6 & 8.2 & 27.3 \\
\hline \multirow[t]{2}{*}{ Dry } & 0 & $+150 /+180$ & 16.5 & 65.0 & 54.7 & 8.8 & 27.5 \\
\hline & $10^{-4} \mathrm{M}$ & $+99 /+130$ & 19.5 & 66.2 & 70.1 & 7.4 & 30.9 \\
\hline
\end{tabular}

${ }^{a}$ Eh measured after 1 min of conditioning time and at the end of flotation.

These figures showed that cuprous cyanide, at levels that could be typically present in the recycled water at Rosh Pinah Mine, can activate sphalerite and increases its recovery in the lead concentrate.

The improved recovery of sphalerite under more positive pulp potentials might be due to one or a combination of the following reasons:

- Oxidation of sphalerite followed by the formation of zinc-xanthate on its surface.

- Oxidation of sphalerite, galena and chalcopyrite followed by the activation of sphalerite by the oxidation products ( $\mathrm{Cu}$ and $\mathrm{Pb}$ ions) of chalcopyrite and galena. The presence of pyrite in the Rosh Pinah ore would also be favourable for the anodic oxidation of sphalerite, chalcopyrite and galena since the rest potential of pyrite is more positive than those of the other sulphide minerals (this assumes that galvanic interactions may occur between the minerals).

- High pulp potentials would also be favourable for the oxidation/decomposition of cuprous cyanide species to $\mathrm{CuO} / \mathrm{Cu}(\mathrm{OH})_{2}$, which are known to activate sphalerite at alkaline $\mathrm{pH}$ values. 
Since the recovery of sphalerite in the lead concentrate has to be minimised for flotation selectivity, it is clear that the presence of cuprous cyanide species and more positive pulp potentials are detrimental to selectivity. The strongest effect of cuprous cyanide is on sphalerite rather than galena; the recovery of galena was not strongly affected by the presence of cuprous cyanide.

Since the decomposition of cuprous cyanide species can also lead to the formation of $\mathrm{CuCN}$, additional flotation tests were carried out at various dosages of $\mathrm{CuCN}$. The Rosh Pinah composite used in this case was from a different batch though with similar chemical composition. Dry milling was selected based on the observed strong activation of sphalerite by cuprous cyanide. The recoveries of sphalerite for different $\mathrm{CuCN}$ dosages are shown in Fig. 8. The results clearly showed that sphalerite was activated by $\mathrm{CuCN}$. The recovery of sphalerite increased from $26 \%$ to $33 \%$ and $46 \%$ when the concentration of $\mathrm{CuCN}$ increased from 0 to $2 \times 10^{-4}$ and $2 \times 10^{-3} \mathrm{M}$. As with $\mathrm{Cu}(\mathrm{CN})_{3}^{2-}$, galena is unaffected by $\mathrm{CuCN}$ additions.
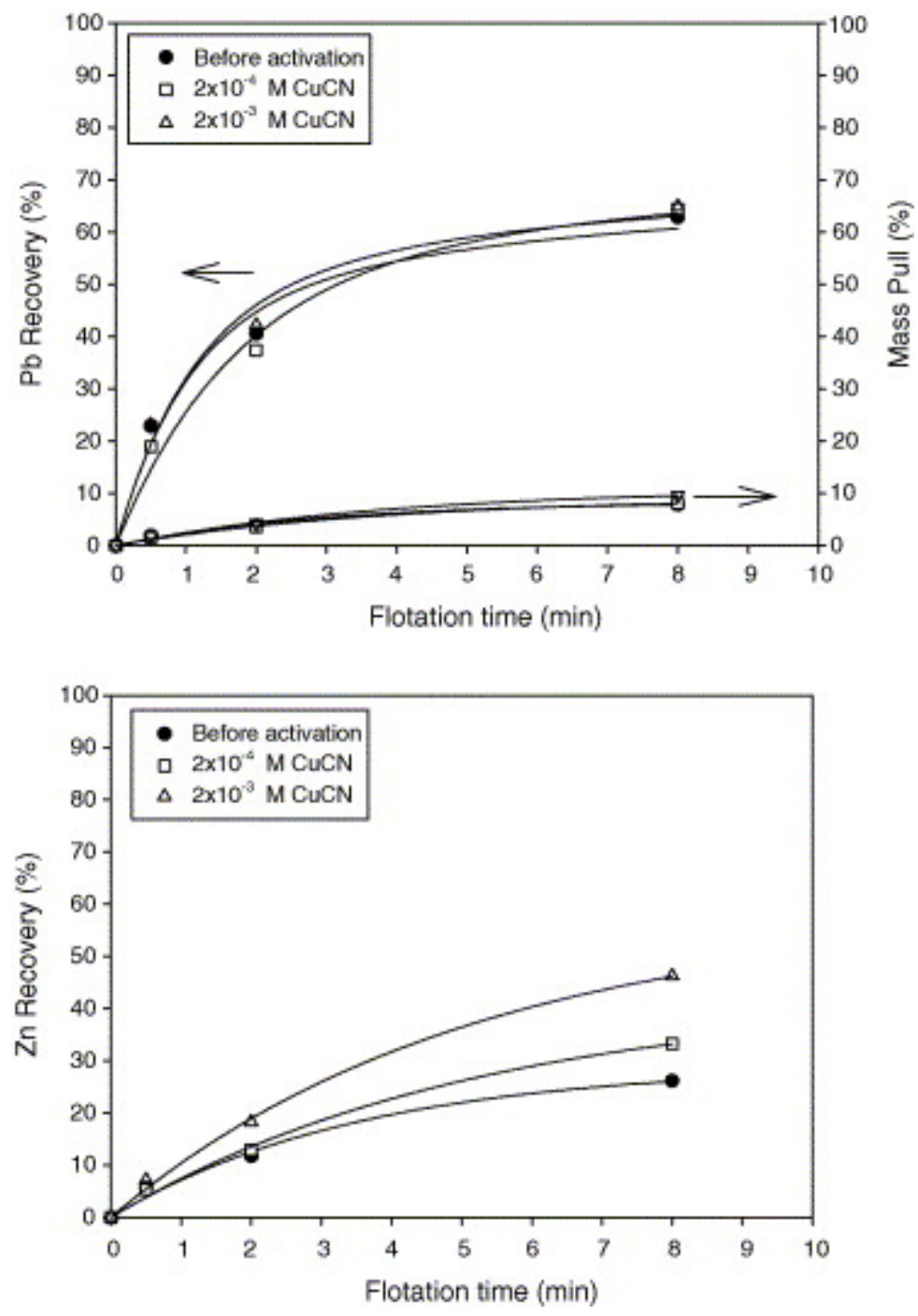
Fig. 8. Effect of $\mathrm{CuCN}$ dosages on the concentrate mass pull and flotation recoveries of galena and sphalerite after wet milling of a Rosh Pinah composite sample. Solid lines represent fitted curves. Flotation conditions: $50 \mathrm{~g} / \mathrm{t} \mathrm{SNPX}$ and $\mathrm{pH}$ 8.5.

In order to understand the mechanism of sphalerite activation by cuprous cyanide, surface analysis of natural sphalerite minerals was conducted. The results are discussed in the following section.

\subsection{X-ray photoelectron spectroscopy on the activation of sphalerite}

Four natural sphalerite samples were conditioned individually in dilute $\mathrm{KOH}(\mathrm{pH} 10.5)$, cuprous cyanide complexes and cupric nitrate solutions in contact with air as explained in Section 3. All elements present on the surface of sphalerite were initially identified in survey mode, and then the various elemental regions were scanned for more details. Background charging is usually observed during the initial examination of the sample in survey mode. When the charging occurs, the binding energy of the $\mathrm{C} 1 \mathrm{~s}$ peak is different from the calibrated value of $284.6 \mathrm{eV}$. Thus, all XPS spectra were charge-corrected accordingly prior to the interpretation of the results. The photoelectron peaks from the sphalerite samples were corrected for background charging by 4.5 and $4.1 \mathrm{eV}$ before and after activation with cuprous cyanide complexes, respectively. The charging decreased from 4.5 to $1.1 \mathrm{eV}$ when the sphalerite was activated with copper nitrate solution, thus indicating the presence of a conducting layer on the surface of sphalerite. The charge shift observed after the activation with cuprous cyanide complexes indicated that the insulating character of sphalerite was maintained and that any copper (as copper sulphide) was likely present in patches.

The charge corrected $\mathrm{Cu} 2 \mathrm{p}$ XPS spectra are presented in Fig. 9. There was no detectable copper on the surface of sphalerite treated with water. The main $\mathrm{Cu} 2 \mathrm{p}_{3 / 2}$ peaks was found at the binding energy of $932.5 \mathrm{eV}$ when the sphalerite was activated with copper nitrate and at the binding energy of $933.7 \mathrm{eV}$ when the sphalerite was activated with cuprous cyanide complexes. The $\mathrm{Cu} 2 \mathrm{p}_{3 / 2}$ binding energies at 932.5 and $933.7 \mathrm{eV}$ are assigned to $\mathrm{Cu}(\mathrm{I})$ species (Kartio et al., 1998). As seen in Fig. 9 there was no shake-up satellite which would be typical of $\mathrm{Cu}(\mathrm{II})$ hydroxide. 

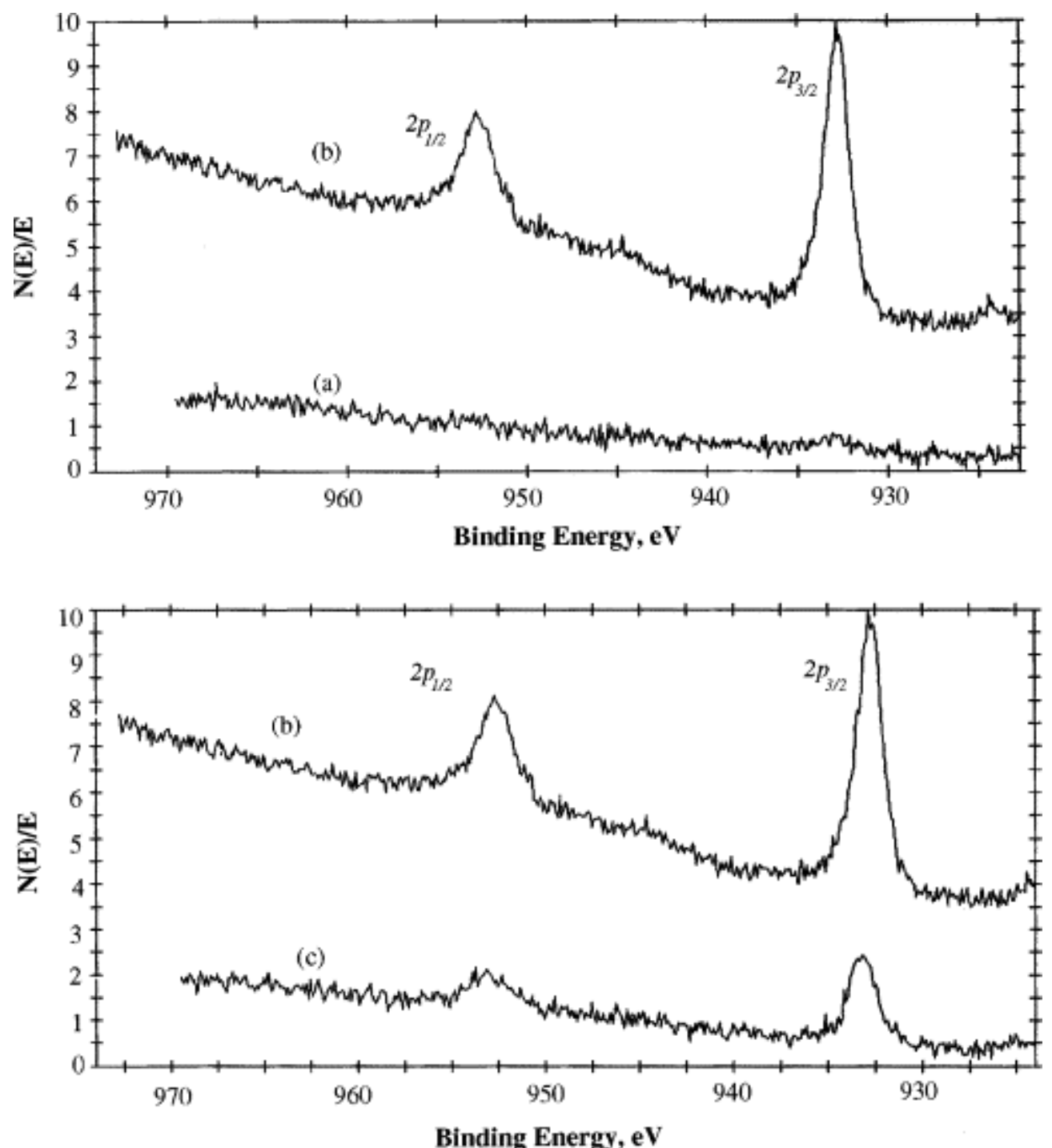

Fig. 9. Normalised XPS spectra in the $\mathrm{Cu} 2 \mathrm{p}$ binding energy of the sphalerite samples treated with (a) water ( $\mathrm{pH} 10.5$ ), (b) $10^{-2} \mathrm{M} \mathrm{Cu}(\mathrm{II})$ from $\mathrm{Cu}\left(\mathrm{NO}_{3}\right)_{2}$, and (c) $10^{-2} \mathrm{M} \mathrm{Cu}(\mathrm{I})$ from $\mathrm{Cu}(\mathrm{CN})_{x}^{[x-1)-}$.

The elemental atomic concentrations of sphalerite samples determined by XPS are given in Table 5. Elemental concentrations were normalised by ignoring the atomic concentration of carbon for a more direct comparison of $\mathrm{Zn}, \mathrm{Cu}, \mathrm{S}$ and $\mathrm{O}$. As expected, sphalerite A, which was conditioned in water (at $\mathrm{pH} 10.5$ ), did not contain any copper on its surface. However, sphalerite B and C, which were treated with copper cyanide complexes, had some copper species on their surfaces. This shows that copper cyanide complexes could activate sphalerite. Sample D was conditioned with copper nitrate for 30 min. Copper nitrate is often used for the activation of sphalerite, and it is known that $\mathrm{Cu}(\mathrm{OH})_{2}$ is the predominant species when zinc sulphide is activated by $\mathrm{Cu}(\mathrm{II})$ ions at 
alkaline pH (Wang et al., 1989a, Wang et al., 1989b and Reddy and Reddy, 1988). As expected, the amount of copper present on the surface of sphalerite was higher on the sample treated with copper nitrate as compared to the sample treated with copper cyanide complexes.

Table 5.

Elemental surface concentrations of copper activated sphalerite samples determined by XPS at $\mathrm{pH} 10.5$

\begin{tabular}{|l|l|l|l|l|l|l|}
\hline Sample & Conditioning & \multicolumn{4}{|c|}{ XPS atomic concentration (\%) } \\
\hline & 30 min & Zn 2p & S 2p & O 1s & N 1s & Cu 2p \\
\hline A & Water (pH 10.5) & 25.7 & 45.4 & 28.9 & 0 & 0 \\
\hline B & $10^{-3} \mathrm{M} \mathrm{Cu}(\mathrm{I})^{\mathrm{a}}$ & 19.0 & 40.0 & 32.1 & 8.6 & 0.3 \\
\hline C & $10^{-2} \mathrm{M} \mathrm{Cu}(\mathrm{I})^{\mathrm{a}}$ & 15.6 & 40.2 & 36.6 & 6.4 & 1.3 \\
\hline D & $10^{-2} \mathrm{M} \mathrm{Cu}(\mathrm{II})^{\mathrm{b}}$ & 3.8 & 36.6 & 46.8 & 9.0 & 4.2 \\
\hline
\end{tabular}

${ }^{a}$ As $\mathrm{Cu}(\mathrm{CN})_{3}^{2-}$.

${ }^{\mathrm{b}} \mathrm{As} \mathrm{Cu}\left(\mathrm{NO}_{3}\right)_{2}$.

The increase in the concentration of copper was accompanied by a larger decrease in the concentration of zinc on the surface of sphalerite. In the case of copper cyanide complexes, the concentration of copper also increased with the initial concentration of $\mathrm{Cu}(\mathrm{I})$ present in solution. The concentration of oxygen in all activated sphalerite samples increased with the concentration of copper. The decrease in the atomic percentage of zinc can be explained by the adsorption of a copper species on the surface of sphalerite. From the results on $\mathrm{B}, \mathrm{C}$ and $\mathrm{D}$, it was clear that more copper species had adsorbed onto the surface when the sphalerite is exposed to copper nitrate than to copper cyanide complexes.

In order to study the effect of free cyanide on the deactivation of copper activated sphalerite, samples previously activated with copper nitrate and copper cyanide complexes were treated with $10^{-2} \mathrm{M} \mathrm{NaCN}$ for $20 \mathrm{~min}$ and then analysed. Elemental surface concentrations of these samples are presented in Table 6. 
Table 6 .

Elemental surface concentrations of cyanide treated sphalerite samples determined by $\mathrm{XPS}$ at $\mathrm{pH} 10.5$

\begin{tabular}{|l|l|l|l|l|l|l|l|}
\hline Sample & Conditioning 1 & Conditioning 2 & \multicolumn{5}{|c|}{ XPS atomic concentration (\%) } \\
\hline & $\mathbf{3 0}$ min & $\mathbf{2 0}$ min & Zn 2p & S 2p & O 1s & N 1s & Cu 2p \\
\hline $\mathrm{E}$ & $10^{-2} \mathrm{M} \mathrm{Cu}(\mathrm{I})^{\mathrm{a}}$ & $10^{-2} \mathrm{M} \mathrm{NaCN}$ & 13.7 & 45.8 & 37.2 & 3.3 & 0 \\
\hline $\mathrm{F}$ & $10^{-2} \mathrm{M} \mathrm{Cu}(\mathrm{II})^{\mathrm{b}}$ & $10^{-2} \mathrm{M} \mathrm{NaCN}$ & 5.7 & 40.3 & 43.9 & 8.7 & 1.5 \\
\hline
\end{tabular}

${ }^{\text {a As }} \mathrm{Cu}(\mathrm{CN})_{3}^{2}=$

${ }^{\mathrm{b}} \mathrm{As} \mathrm{Cu}\left(\mathrm{NO}_{3}\right)_{2}$.

These results showed that there was complete copper removal from the surface of sphalerite in the case of sample E, which had previously been treated with copper cyanide complexes. In the case of sample F, which had been activated by copper nitrate, only partial removal of copper species was achieved after $20 \mathrm{~min}$. This is probably due to the difference in the concentration of adsorbed copper when sphalerite was initially activated with cuprous cyanide and copper nitrate (Table 5).

The atomic concentration of oxygen was reduced when sphalerite which had been activated by $\mathrm{Cu}(\mathrm{II})$ was treated with cyanide. This is in agreement with the results of Prestidge et al. (1997). This could reflect the removal of $\mathrm{Cu}(\mathrm{OH})_{2}$ from the surface of the sphalerite. Prestidge et al. (1997) also reported that the effectiveness of deactivation by cyanide is dependent on the form of copper at surface which, in turn, is controlled by the concentration of copper(II) during activation, $\mathrm{pH}$, electrochemical potential, and times for activation and deactivation. Prestidge et al. (1997) used various dosages of $\mathrm{Cu}$ (II) to study the copper-surface coverage of sphalerite, and hence calculated the equivalent number of adsorbed copper monolayer.

It is concluded that copper abstraction from the surface of sphalerite can be achieved by adding excess cyanide to the pulp. The increase in free cyanide concentration during the depression of sphalerite by addition of sodium cyanide should leach out copper that had previously adsorbed onto the surface of sphalerite by complexation of cuprous cyanide species. Thus, it is believed that an excess of cyanide may be required to keep copper in solution as copper cyanide complexes rather than adsorbing onto the surface of sphalerite during the flotation of lead concentrate. 


\section{Conclusion}

The effects of the grinding environment and copper cyanide complexes on the flotation of the lead-zinc sulphide composite from the Rosh Pinah deposit were studied.

Measurements of the pulp potential have indicated that the grinding environment (wet and dry milling) can influence the pulp potential and subsequently the surface properties of the mineral to be floated. It was observed that:

- More positive pulp potentials were measured when the composite had been ground in a dry environment. The difference in pulp potentials between the dry and wet ground composite was approximately $260 \mathrm{mV}$ after the grinding stage.

- The recovery of sphalerite from the complex lead-zinc sulphide composite was higher when the composite was milled in a dry environment compared with the wet environment. In addition, the recovery of galena decreased after milling in a dry environment, while wet milling improved its recovery. The net effect was that the flotation selectivity between galena and sphalerite was improved by wet milling.

- Batch flotation and XPS results have demonstrated that copper cyanide complexes can activate sphalerite. The activation and subsequent flotation of sphalerite was greater after dry milling.

The results presented in this study have confirmed that the flotation selectivity of complex sulphide ore depends on the electrochemical potential of the pulp. Thus, controlling the pulp potential during the milling stage would have a significant impact on the conditioning and flotation response of the complex ores, because the excessive oxidation of minerals and grinding media generates oxidation products that are usually detrimental to flotation.

\section{References}

Broman, 1980 P.G. Broman, Water reuse at sulphide ore concentrates in Sweden: practice, experience and current developments. In: M.J. Jones, Editor, Complex sulphide ores, Institution of Mining and Metallurgy, London (1980), pp. 28-39.

Buckley and Woods, 1997 A.N. Buckley and R. Woods, Chemisorption - the thermodynamically favoured process in the interaction of thiol collectors with sulphide minerals, Int. J. Miner. Process. 51 (1997), pp. 15-26.

Casella and Gatta, 2000 I.G. Casella and M. Gatta, Anodic electrodeposition of copper oxide/hydroxide films by alkaline solutions containing cuprous cyanide ions, $J$. Electroanal. Chem. 494 (2000), pp. 12-20. 
Chen and Yoon, 2000 Z. Chen and R.H. Yoon, Electrochemistry of copper activation of sphalerite at pH 9.2, Int. J. Miner. Process. 58 (2000), pp. 57-66.

Cheng et al., 2002 S.C. Cheng, M. Gattrell, T. Guena and B. MacDougall, The electrochemical oxidation of alkaline copper cyanide solutions, Electrochim. Acta 47 (2002), pp. 3245-3256.

Coetzer et al., 2003 G. Coetzer, H.S. Du Preez and R. Bredenhann, Influence of water resources and metal ions on galena flotation of Rosh Pinah ore, J. South Afr. Inst. Min. Metall. 103 (2003) (3), pp. 193-207.

Crozier, 1991 R.D. Crozier, Sulphide collector mineral bonding and the mechanism of flotation, Miner. Eng. 4 (1991) (7-11), pp. 839-858.

Djokić, 2002 S.S. Djokić, Electroless deposition of metals and alloys. In: B.E. Conway and R.E. White, Editors, Modern aspects of electrochemistry vol. 35, Kluwer Academic/Plenum Publishers (2002), pp. 51-133.

Dudek and Fedkiw, 1999 D.A. Dudek and P.S. Fedkiw, Electrodeposition of copper from cuprous cyanide electrolyte. I. Current distribution on a stationary disk, J. Electroanal. Chem. 474 (1999), pp. 16-30.

Finkelstein, 1997 N.P. Finkelstein, The activation of sulphide minerals for flotation: A review, Int. J. Min. Process. 52 (1997), pp. 81-120.

Huang, 2003 H.H. Huang, Stabcal Software: Stability Calculation for Aqueous Systems, Metall. Eng. Montana Tech. (USA) (2003).

Kartio et al., 1998 I.J. Kartio, C.I. Basilio and R.H. Yoon, An XPS study of sphalerite activation by copper, Langmuir 14 (1998), pp. 5274-5278.

Laskowski et al., 1997 J.S. Laskowski, Q. Liu and Y. Zhan, Sphalerite activation: flotation and electrokinetic studies, Miner. Eng. 10 (1997) (8), pp. 787-802.

Levay et al., 2001 G. Levay, R.St.C. Smart and W.M. Skinner, The impact of water quality on flotation performance, J. South Afr. Inst. Min. Metall. 101 (2001) (2), pp. 6975.

Light, 1972 T.S. Light, Standard solution for redox potential measurements, Anal. Chem. 44 (1972) (6), pp. 1038-1039.

Lukey et al., 1999 G.C. Lukey, J.S.J. Van Deventer, S.T. Huntington, R.L. Chowdhury and D.C. Shallcross, Raman study on the speciation of copper cyanide complexes in highly saline solutions, Hydrometallurgy 53 (1999), pp. 233-244. 
Malysiak et al., 2003 Malysiak, V., Shackleton, N.J., de Vaux, D., 2003. Effect of water quality on pentlandite-pyroxene floatability with emphasis on calcium ions. In: Lorenzen, L., Bradshaw, D. (Eds.), Proc. of the 22nd International Mineral Processing Congress, Cape Town, South Africa, 29 September-03 October 2003, pp. 734-742.

Ng'andu, 2001 D.E. Ng'andu, The effect of underground mine water on the performance of the Mufulira flotation process, J. South Afr. Inst. Min. Metall. 101 (2001) (7), pp. $367-$ 380 .

Pattrick et al., 1999 R.A.D. Pattrick, K.E.R. England, J.M. Charnock and J.F.W. Mosselmans, Copper activation of sphalerite in relation to flotation: an X-ray absorption spectroscopy (reflection extended X-ray absorption fine structure) investigation, Int. $J$. Min. Process. 55 (1999), pp. 247-265.

Prestidge et al., 1997 C.A. Prestidge, W.M. Skinner, J. Ralston and R.C. Smart, Copper (II) activation and cyanide deactivation of zinc sulphide under mildly alkaline conditions, Appl. Surf. Sci. 108 (1997), pp. 333-344.

Rao, 1971 S.R. Rao, Xanthates and related compounds, Marcel-Dekker (1971).

Rao and Finch, 1989 S.R. Rao and J.A. Finch, A review of water re-use in flotation, Miner. Eng. 2 (1989) (1), pp. 65-85.

Reddy and Reddy, 1988 G.S. Reddy and K. Reddy, The chemistry of activation of sphalerite. A review, Miner. Process. Extr. Metall. Rev. 4 (1988), pp. 1-37.

Seke, 2005 Seke, M.D., 2005. Optimisation of the Selective Flotation of Galena and Sphalerite at Rosh Pinah Mine. PhD Thesis. University of Pretoria, Pretoria (South Africa).

Wang et al., 1989a X. Wang, E. Forssberg and N.J. Bolin, The aqueous and surface chemistry of activation in the flotation of sulphide minerals. A review. Part. 1: An electrochemical model, Miner. Process. Extr. Metall. Rev. 4 (1989), pp. 135-165.

Wang et al., 1989b X. Wang, E. Forssberg and N.J. Bolin, The aqueous and surface chemistry of activation in the flotation of sulphide minerals. A review. Part II: A surface precipitation model, Miner. Process. Extr. Metall. Rev. 4 (1989), pp. 67-199.

Williams and Phelan, 1985 S.R. Williams and J.M. Phelan, Process development at Woodlawn Mines. In: A.D. Zunkel, R.S. Boorman, A.E. Morris and R.J. Wesely, Editors, Complex sulphides. Processing of ores, concentrates and by-products, The AIME, Pennsylvania (1985), pp. 293-304. 